\title{
Rh FREQUENCY IN THE PEOPLE OF LUCKNOW
}

D. N. MAJUMDAR

Anthropology Laboratory, Lucknow University, India

Received 16.xii. 47

HUMaN erythrocytes contain a variety of antigenic components$A$ and $B, M$ and $N$ and the $R h$ series. The agglutinogen $R h$ has been shown to have no relation with the $\mathrm{ABO}$ groups.

The importance of the $\mathrm{Rh}$ series lies in the fact that an $\mathrm{Rh}$ negative woman who is pregnant with a foetus whose blood cells are positive can develop an antibody against the agglutinogen, and in addition, any $\mathrm{Rh}$ negative person may form such an antibody against the agglutinogen if transfused with $\mathrm{Rh}$ positive blood. $\mathrm{Rh}$ positive infants usually develop jaundice or anæmia, or are still-born if the mother has developed the $\mathrm{Rh}$ antibody. Recent studies in the U.S.A., however, point to the fact that the incompatibility of the $\mathrm{Rh}$ factor in mother and foetus is unimportant in the production of premature abortions, and in the etiology of hæmolytic icterus, ectopic pregnancies, etc. (Schwartz and Levine, 1943). In any case, the genetics of the $\mathrm{Rh}$ factor and the understanding of it have increased tremendously in recent years, and the racial significance of its varying frequencies, as well as those of the agglutinogens $\mathrm{M}$ and $\mathrm{N}$ is now becoming clear. As Mourant (1947) puts it the present $\mathrm{Rh}$ ratio in Western Europe is an unstable one, and one is led to postulate a mixing of populations predominantly $\mathrm{Rh}$-positive and $\mathrm{Rh}$-negative respectively within the last few thousand years.

Khanolkar and Sanghvi, in discussing their results, suggest that " differences between our (their) results and those of other workers in India may be due to the fact that they have been using serum (after suitable dilutions) of animals immunised with red cells of rhesus monkeys." They say further, that "such immunisation leads to the development of anti-Rh as well as other agglutinogens to a variable extent."

During a racial and serological survey of Bengal, which I carried out in 1945 at the invitation of Prof. P. C. Mahalanobis, financed by the Indian Statistical Institute, Calcutta, I was supplied with some dried human anti-Rh testing sera from the Galton Serum Unit at Cambridge, sent by Dr G. L. Taylor for use during the Survey. When the Bengal Survey was completed in July 1945, I had to return to duty at Lucknow, and I brought some of the sera with me for testing people there. Without further absorption, the anti-Rh sera 
from England could not be used against any group other than $\mathrm{A}$ and $\mathrm{O}$, so that these alone were tested. The technique followed was that of Taylor (1943).

TABLE I

Tests against $A$ and $O$

\begin{tabular}{|c|c|c|c|c|c|c|c|c|}
\hline \multirow{2}{*}{\multicolumn{2}{|c|}{ Subjects }} & & \multicolumn{2}{|c|}{ A } & \multicolumn{2}{|c|}{$\mathrm{O}$} & \multicolumn{2}{|c|}{ Total } \\
\hline & & & $\mathrm{Rh}+$ & $\mathrm{Rh}-$ & $\mathrm{Rh}+$ & $\mathrm{Rh}-$ & $\mathbf{R h}+$ & $\mathrm{Rh}-$ \\
\hline \multicolumn{9}{|l|}{ BRAHMINS : } \\
\hline Male . & . & . & 8 & 0 & 5 & o & & \\
\hline $\begin{array}{l}\text { Female. } \\
\text {. }\end{array}$ & - & - & 6 & I & 3 & 0 & 22 & I \\
\hline \multicolumn{9}{|l|}{ KAYASTHAS : } \\
\hline $\begin{array}{l}\text { Male } \\
\text { Female. }\end{array}$ & - & - & 5 & 0 & 9 & 0 & & \\
\hline \multicolumn{8}{|l|}{ Muslims : } & o \\
\hline Male. & & . & 9 & I & 6 & o & & \\
\hline Female chi & & . & 5 & 0 & 6 & 0 & 26 & $\mathrm{I}$ \\
\hline \multicolumn{9}{|l|}{ ChamaRs : } \\
\hline Male . & . & . & 4 & 0 & 6 & 2 & & \\
\hline $\begin{array}{l}\text { Female . } \\
\text { Doms : }\end{array}$ & & 0 & 5 & 0 & $2 \mathrm{I}$ & 2 \\
\hline $\begin{array}{c}\text { Doms : } \\
\text { Male }\end{array}$ & . & . & 5 & I & 7 & 0 & & \\
\hline Female . & . & . & 3 & 0 & . & $\mathrm{I}$ & $2 \mathrm{I}$ & 2 \\
\hline Total & . & . & 57 & 3 & 53 & 3 & I 2 & 6 \\
\hline \multicolumn{9}{|c|}{ Percentage of $R h-5.45$} \\
\hline
\end{tabular}

TABLE 2

Frequencies of $R h \rightarrow$ individuals in various populations

\begin{tabular}{|c|c|c|c|}
\hline Population & $\begin{array}{l}\text { Number } \\
\text { examined }\end{array}$ & Percentage & Authority \\
\hline Chinese & 132 & I $\cdot 5$ & Wiener, Sonn and Belkin (1 945) \\
\hline Indians & I00 & $2 \cdot 0$ & Khanolkar and Sanghvi (1945) \\
\hline Lucknow Indians & 116 & 5.45 & Majumdar (see table I) \\
\hline Negroes (U.S.A.) & 223 & $8 \cdot 1$ & Wiener (1944). \\
\hline Jews (Canada) & 967 & $8 \cdot 37$ & Lubinski, Benjamin and Strean \\
\hline Calcutta Indians & 200 & $10 \cdot 0$ & Greval and Chowdhury (1943) \\
\hline "’ "’'Folich jutitej & 240 & $10 \cdot 0$ & Das Gupta (1 944) \\
\hline $\begin{array}{l}\text { American and English (white) } \\
\text { South Americans }\end{array}$ & $\begin{array}{ll}\cdots \\
\text { II } 2\end{array}$ & $\begin{array}{l}15 \cdot 0 \\
17 \cdot 86\end{array}$ & $\begin{array}{l}\text { Landsteiner and Wiener (1940) } \\
\text { Invernizzi and Yannicelli (1944) }\end{array}$ \\
\hline Basques (Argentine) & $25^{\circ}$ & & $\begin{array}{l}\text { Etcheverry (quoted by Mourant } \\
(\text { ( } 947))\end{array}$ \\
\hline
\end{tabular}

The results of the Bengal Survey have been published in full (Majumdar and Kishen, 1947).

\section{SUMMARY}

The present results agree with the general scheme of world variation in the $\mathrm{Rh}$ gene which we may arrange as in table 2. Here 
we see that the Indian populations stand between the low extreme in China and the high extreme in the Basque population.

\section{REFERENCES}

DAS GUPTA, C. R. $\quad$ I 944 .

Ind. med. Gaz. 37, 372.

GREVAL, S. D. S., AND GHOWDHURY, A. B. R. I 943.

F. Ind. med. Ass. ${ }_{3}, 65$.

INVERNIZZI, D., AND YANNIGELLI, S. I 944 .

Arch. Uruguayo med. Cir. : y Esp. 25 (2), I 85.

KHANOLKAR, V. R., AND SANGHVI, L. D. 1945 .

Nature, Lond. 155, 427-428.

LANDSTEINER, K., AND WIENER, A. S. 1940.

Proc. Soc. exp. Biol. N.Y. 42, 223.

LUBINSKI, H. B., BENJAMIN, -., AND STREAN, G. J. 1945.

Canada med. Ass. F. 53, 28.

MAJUMDAR, D. N., AND KISHEN, K. 1947.

Eastern Anthropologist I, I.

MOURANT, A. E. 1947.

Nature, Lond. $160,505$.

SGHWARTZ, H. H., AND LEVINE, P. 1943.

Amer. F. Obs. Gyn. 46,827 .

TAYLOR, G. L. 1943.

Proc. Soc. Med. 36, 225.

WIENER, A. S., SONN, E. B., AND BELKIN, R. B. I 944 .

Amer. F. Phys. Anth. n.s., 2, 187.

WIENER, A. S., SONN, E. B., AND BELKIN, R. B. 1945.

7. Immunol. 5o, 6. 